\title{
Oktatási anyagok és didaktikai eszközök a mérnökképzési gyakorlatokban
}

\section{Educational Materials and Didactic Tools in Engineering Training Practices}

\author{
Bitay Enikő, ${ }^{1}$ Bagyinszki Gyula ${ }^{2}$ \\ ${ }^{1}$ Sapientia Erdélyi Magyar Tudományegyetem, Marosvásárhelyi Kar, Marosvásárhely, Románia, \\ ebitay@ms.sapientia.ro \\ 2 Óbudai Egyetem, Bánki Donát Gépész és Biztonságtechnikai Mérnöki Kar, Budapest, Magyarország, \\ bagyinszki.gyula@bgk.uni-obuda.hu
}

\begin{abstract}
Educational materials are closely related to educational (didactic) tools, as they allow their preparation and presentation. The production of technical higher education (engineering training) materials or preparation can be approached from many perspectives. This article deals with some aspects of this.

Keywords: education, training, didactics, materials, tools.

\section{Összefoglalás}

Az oktatási anyagok szoros összefüggésben vannak az oktatástechnikai (didaktikai) eszközökkel, hiszen ezen eszközök teszik lehetővé elkészítésüket, bemutatásukat. A műszaki felsőoktatási (mérnökképzési) anyagok előállítását, ill. előkészítését sokféle szempontból lehet megközelíteni. Jelen cikk ennek néhány aspektusával foglalkozik.
\end{abstract}

Kulcsszavak: oktatás, képzés, didaktika, anyagok, eszközök.

\section{Bevezetés}

Az [1]-ben foglalkoztunk a mérnökképzés oktatási módszereivel, a [2]-ben a műszaki felsőoktatás tananyag- és oktatásszervezési szempontjaira hívtuk fel a figyelmet, míg a [3]-ban a mérnökképzés gyakorlatainak szerepét, funkcióit és formáit tekintettük át. A [4]-ben pedig egy konkrét szakterületi példát választva mutattuk be a módszertani szempontokat.

A mérnökképzés tanterveiben előírt gyakorlati foglalkozások oktatási anyagai szempontjából egyik fontos tényező a helyszín, ill. a tárgyi környezet, ahol ezen anyagok felhasználásra kerülnek. Ha a gyakorlati foglalkozást olyan helyen szervezik meg, ahol az adott téma üzemi körülmények közötti bemutatása lehetséges, akkor egyszerübb anyagok készítésével is hatékonnyá tehető a bemutatás, mivel a vonatkozó dolgok „egyből élesben” szemléltethetők.
Meghatározó tényező a felhasznált eszközök, anyagok korszerüsége a képzés minősége, de az illetékes tanszék vagy intézet megítélése szempontjából is. Ehhez meg kell teremteni az anyagi feltételeket és a befogadó műszaki környezet általános és szakmai színvonalát.

Törekedni kell arra is, hogy az így elkészített oktatási anyag ne csak egyedi eseteket, hanem az adott feladat kapcsán felmerülő variánsokat is tartalmazó, univerzális taneszköz legyen. Természetesen nem elhanyagolandó szempont az esztétikus kivitel és a precíz kidolgozás sem.

Számítási, tervezési, anyagválasztási feladatok megoldását hatékonyabbá teszi, a hallgatók jobb hozzáállását elősegíti, ha az adott feladat fontosabb szakirodalma, kézikönyvei, szabvány(kivonat)ai és egyéb segédletei „könyvtárazva”, lehetőleg széleskörűen rendelkezésre állnak a foglalkozás helyszínén. 
A rajzos, fényképes tablóknál vagy vetített képeknél sokkal hatásosabbak lehetnek a konkrét, valódi tárgyakból (pl. egy termék közbenső gyártási állapotaiból) összeállított anyagok, amelyek életszerübben (kézzel foghatóan) mutathatnak be akár folyamatokat is, nemcsak objektumokat.

\section{Többcélú oktatási anyagok}

Vannak olyan oktatásban felhasznált anyagok, amelyeket több vonatkozásban, többféle megjelenési formában is fel lehet használni. Például ilyen lehet egy anyagvizsgálati próbatest, amelyet csiszolatkészítés után fényképfelvételekhez (makroszkopikus és mikroszkopikus változatban), vagy az alkalmazott technológia (pl. felületkezelés) hatásának bemutatáshoz egyaránt fel lehet használni. Ez nem csak oktatástechnológiai kérdés, hanem gazdaságossági szempont is. $\mathrm{Az}$ 1. ábra példaképpen felületkezelési technológia minősítésére szolgáló sémát mutat, melyhez az anyagvizsgálati próbatesten végezhető:

-fénymikroszkópiszövetszerkezet- és szemcseméret-vizsgálat,

-elektronmikroszkópi fázis- és ötvözőanalízis,

-mélységirányú keménységmérés.

További próbatestsorozattal - keménységmérések révén - pedig a megeresztésállóság (meleg-kopásállóság) is jellemezhető. Az 1. ábrán bemutatott példa egyfajta kísérlettervezési ajánlásként is funkcionálhat a hallgatók részére, ha ilyen témában tudományos diákköri dolgozatot, szakdolgozatot, diplomamunkát készítenek.
Nehezen vagy túl költségesen megvalósítható folyamatoknál pedig célszerű egyidejüleg többféle dokumentálási formát alkalmazni:

-fotósorozat-készítés,

- videófilm-rögzítés,

- számítógépes adatgyưjtés,

- egyéb (az alkalmazott módszerre, ill. berendezés-

re speciálisan jellemző) papíron és//vagy elektronikusan rögzíthető regisztrátumok készítése.

Ezt megfelelő oktatói-laboránsi kooperációval lehet megvalósítani, akik tisztában vannak azzal, hogy a folyamat mely mozzanatait kell feltétlenül rögzíteni a megfelelő kiértékelhetőség érdekében.

Számolási, tervezési vagy méréskiértékelési feladatokhoz egyaránt készíthetők programok, applikációk az oktató, a hallgatók, külső szakember vagy akár demonstrátorok által. Ilyen jellegű alkalmazásoknál a fő szempont ne a program „kidíszítése” legyen, hanem a praktikusság és a hibamentes futás.

\section{Didaktikai eszközök és funkciók}

Az oktatástechnikai (didaktikai) eszközök szempontjából a funkciókat rendszerezve, négyre szűkíthetjük a számukat. A didaktikai eszközök ugyanis fokozzák a képzési folyamat hatékonyságát, mivel megkönnyítik a tanulóknak:

- a valóság megismerését,

- a valóságra vonatkozó ismeretek elsajátítását, - a valósághoz füződő érzelmi viszonyok alakítását, - a valóságot átalakító tevékenység fejlesztését.

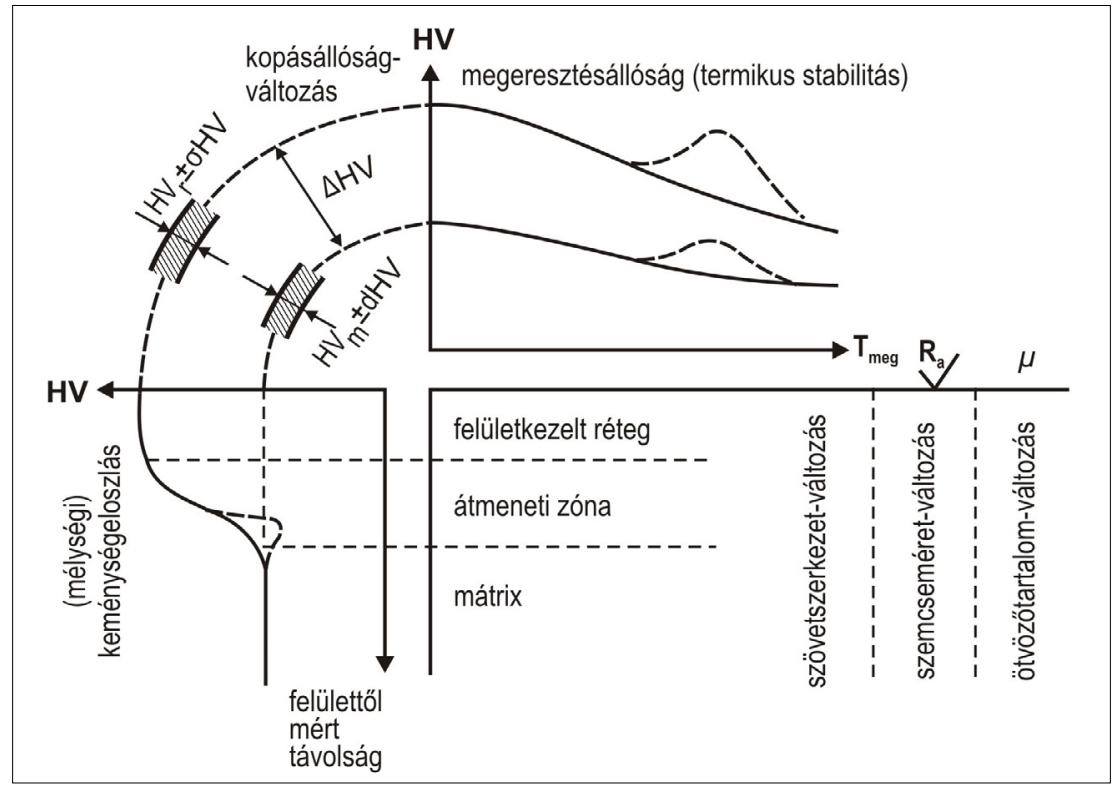

1. ábra. Felületkezelési rétegminősités sémája 
A didaktikai eszközök osztályozásainak többsége nem veszi figyelembe mind a négy funkciót. Általában a valóság megismerésére helyezik a hangsúlyt, méghozzá a látás és a hallás segítségével, amit a közismert „audiovizuális eszközök” kifejezés is tükröz. Az igazán jó didaktikai eszközök valamennyi érzékszervet igénybe veszik. A három utóbbi funkció azonban rendszerint figyelmen kívül marad, pedig megkönnyítik a hallgatók számára a valóságban való tájékozódást, ill. a valóság formálását (2. ábra) [5, 6]:

Oktatástechnikai (didaktikai) eszközök általános felosztása hat kategóriát különböztet meg:

1. Verbális eszközök (nyomtatott taneszközök):

- Tanári segédletek: kézikönyvek, szakkönyvek, feladatgyưjtemények, (szak)folyóiratok, táblai szövegek és vázlatok, tantárgytesztek, bibliográfiák;

- Hallgatói segédletek, tankönyvek: kötelező és ajánlott szakirodalom, munkafüzetek, munkalapok, feladatlapok, tevékenységre vonatkozó nyomtatott útmutatók, kézikönyvek, szótárak, szöveggyüjtemények, tervezési segédletek, példatárak, (szak)folyóiratok, gyakorlati (mérési) útmutatók és jegyzőkönyvi űrlapok.

2. Egyszerű vizuális eszközök:

- Tanári demonstrációs eszközök: természetes tárgyak, anyagminta-gyüjtemények, preparátumok, munkatermékek, tablók, poszterek, kísérleti eszközök, utánzatok, applikációs eszközök, taktilis (megfogható) eszközök, mérőeszközök, metszetek, próbatestek;

- Hallgatói kísérleti eszközök: manipulációs eszközök, vizsgálati eszközök, laboratóriumi készletek, modellek, applikációs eszközök, mérőeszközök.
3. Képek regisztrálását, tárolását és átadását lehetővé tevő vizuáltechnikai eszközök: fényképezőgép, mikroszkóp, endoszkóp, számítógép, adathordozó.

4. Hangok és zajok átadását lehetővé tevő auditív technikai eszközök: médialejátszók.

5. Hangot és képet egyesítő audiovizuális eszközök: kamera, médialejátszó, televízió, monitor; hangosfilmet (8, 16 és $35 \mathrm{~mm}$-es) digitalizáló és archiváló eszközök.

6. Az oktatási folyamatot automatizáló eszközök: nyelvi laboratórium, számítógép, regisztráló- és sokszorosítóeszközök.

$\mathrm{Az}$ oktatástechnikai eszközöket (médiumokat) az alábbiak szerint rendszerezhetjük [7]:

1. Nyomtatott taneszközök (könyvek, segédletek, feladatlapok).

2. Auditív információhordozók (médiafelvevők és lejátszók; hanglemezt, hangszalagot, hangkazettát digitalizálók és archiválók).

3. Információhordozók (kamerák és médialejátszók; diafilmet, keretezett diát, transzparens átvetíthető modellt, hangos- és némafilmet digitalizálók, ill. archiválók).

4. Audiovizuális információhordozók (internetes videócsatornák és hordozható médialejátszók, webkonferencia-platformok; hangosfilmet, hangosított diát, videólemezt, videókazettát, videómagnetofon-szalagot digitalizálók és archiválók).

5. Tanulókísérleti eszközök.

6. Tanári demonstrációs eszközök.

7. Oktatástechnikai eszközök.

8. Oktatócsomagok, távoktatási tananyagok.

9. Számítógépek és tanulást segítő szoftverek.

\begin{tabular}{|c|c|c|}
\hline \multicolumn{2}{|r|}{ Didaktikai funkciók } & \multirow{2}{*}{\begin{tabular}{|l|} 
Eszközök (péidák) \\
- természetes tárgyak, képek \\
- helyettesítő tárgyak, képek \\
- modellek, makettek, tervrajzok \\
\end{tabular}} \\
\hline A valóság megismerése & $\begin{array}{l}\text { - természetes formában } \\
\text { - helyettesítő formában } \\
\text { - általánosított formában }\end{array}$ & \\
\hline $\begin{array}{l}\text { A valóságra vonatkozó } \\
\text { ismeretek elsajátítása }\end{array}$ & $\begin{array}{l}\text { - ismeretek közlése } \\
\text { - ismeretek közlése technikai eszközök } \\
\text { segítségével } \\
\text { • ismeretek közlése önálló munkával } \\
\text { egybekötve }\end{array}$ & $\begin{array}{l}\text { - nyomtatott szövegek } \\
\text { • tablók, vetített képek és prezentációk } \\
\text { • tankönyvek, szakkönyvek és feladatlapok }\end{array}$ \\
\hline $\begin{array}{l}\text { A valósághoz füződő } \\
\text { érzelmi viszonyok } \\
\text { alakítása }\end{array}$ & $\begin{array}{l}\text { • közösségi nevelés } \\
\text { • zenei nevelés } \\
\text { • képzőmúvészeti nevelés }\end{array}$ & $\begin{array}{l}\text { • nyomtatott szövegek, elektronikus média } \\
\text { • zenelejátszó eszközök } \\
\text { • képzőművészeti alkotások, másolatok, } \\
\text { elektronikus média }\end{array}$ \\
\hline $\begin{array}{l}\text { A valóságot átalakító } \\
\text { tevékenység fejlesztése }\end{array}$ & $\begin{array}{l}\text { - nyelvi és szimbolikus készségek } \\
\text { - kutatási készségek } \\
\text { - műszaki készségek }\end{array}$ & $\begin{array}{l}\text { • oktatástechnikai eszközök, nyelvi labora- } \\
\text { tóriumok } \\
\text { • laboratóriumi anyagok, eszközök, berende- } \\
\text { zések, szimulátorok } \\
\text { • munkaeszközök, gépek, múszerek, makettek }\end{array}$ \\
\hline
\end{tabular}


A felsorolásban szerepelnek „elavult”-nak tekintett információhordozók nevei is, viszont fontos feladat, hogy a még „megmenthető” (esetenként pótolhatatlan) és egyébként a képzésben jól hasznosítható anyagokat digitalizáljuk, archiváljuk és természetesen használjuk is.

\section{A videotechnika és informatika szerepe}

A videotechnika - mint leginkább érdeklődéskeltő és figyelmet (talán) jobban lekötő eszköz, ill. média - alkalmazásának fontosabb felsőoktatási funkciói az alábbiakban foglalhatók össze:

- Az önismeret (énkép) fejlesztése, személyiség- és képességfejlesztés. A visszajátszható videófelvétel bemutatja a hallgatóknak, miként viselkedtek egy adott tanítási, beavatkozási vagy kísérleti szituációban.

- Kísérletek, nagyon gyors vagy igen lassú fizikai események, mikroszkopikus méretű történések bemutatása. Videóval „kimerevíthetjük” a képet, újra és újra egyszerúen visszajátszhatjuk a felvételt, ill. annak egyes mozzanatait.

-Élő közvetítés. Online oktatási platform segítségével „élő adásban” mutathatunk be tanórát, bonyolult kísérletet stb.

-Dokumentációs felvétel. Egy hosszabb eseményt, történést teljes egészében rögzítünk, és szerkesztve vagy szerkesztés nélkül, részleteiben vagy egészében vetíthetünk.

- Mikrotanítás. Olyan egyszerüsített, de valósághü helyzet, amely kedvező feltételeket biztosít (különösen a kezdő) oktató számára ahhoz, hogy új tanítási készségeket sajátítson el, vagy a már korábban megismerteket tökéletesítse.

Az informatika (számítástechnika) pedagógiai alkalmazásában két alapvető területet kell figyelembe venni: a hardver- és szoftverfejlesztéseket. A hardverfejlesztést a pedagógia vonatkozásában adottnak tekinthetjük abban az értelemben, hogy ezt a folyamatot alapvetően a „globális” gazdasági és tudományos igények határozzák meg [8].

A számítógépes programok (szoftverek) fejlesztési szempontjai:

- a program alapvető pedagógiai célja: oktatási, szakképzési, pályaorientációs;

- a program tartalma: jellemző legyen a tervszerűség és szervezettség, ill. a jó illeszkedés a nevelő-oktató, képző munka folyamatába;

-fő didaktikai feladatai: oktatás, képzés egyes területeinek segítése:

- motivációs, demonstrációs, szimuláló, modellező, gyakorló, rendszerező, alkalmazó, problémamegoldó, mérési kultúrát fejlesztő, ellenőrző, önellenőrző, teljesítményértékelő, a tanítá- si-tanulási folyamatot diagnosztizáló, oktatási hatékonyságot vizsgáló programok [8, 9];

- a megcélzott felhasználók:

- az intézmény nevelői-tanulmányi és/vagy adminisztrációs és gazdasági vezetése, tanárok, oktatók, hallgatói nagycsoportok, hallgatói kiscsoportok, egyes hallgatók.

Természetesen a hallgatói kiscsoportoknak, ill. az egyes hallgatóknak szánt programok felhasználásához biztosítani kell a megfelelő hardverhátteret is. Lehetőleg minél kedvezőbb körülmények álljanak rendelkezésre az ilyen számítógéppark hozzáféréséhez és használatához.

\section{Következtetés}

Az oktató maga a legfőbb információs forrás, ő szervezi és irányítja a médiumokat, visszajelzéseket kap a hallgatóktól, melyek alapján beavatkozhat, korrigálhatja az oktatási folyamatot. Az oktatástechnikai (didaktikai) eszközök elősegítik a foglalkozások szemléletessé tételét, információkat nyújtanak, lehetővé teszik, hogy a hallgatók jártasságaikat tökéletesítsék, és gyakorlatot szerezzenek, fejlesszék szellemi képességeiket, elsajátítsák a tudományos kutatás gyakorlatát.

\section{Szakirodalomi hivatkozások}

[1] Bagyinszki Gy., Bitay E.: Mérnökképzés oktatási módszerei. Müszaki Tudományos Közlemények, 13. (2020) 19-23.

https://doi.org/10.33895/mtk-2020.13.02

[2] Bagyinszki Gy., Bitay E.: Tananyag-és oktatásszervezés a müszaki képzésekben. Müszaki Tudományos Közlemények, 11. (2019) 23-26.

https://doi.org/10.33895/mtk-2019.11.02

[3] Bagyinszki Gy., Bitay E.: Anyagtudományi gyakorlat-modulok a gépész- és mechatronikai mérnök képzésben. Múszaki Tudományos Füzetek, 16. (2011) 5-16.

https://doi.org/10.36243/fmtu-2011.04

[4] Bitay E., Bagyinszki Gy.: Hegesztőrobotokra vonatkozó ismeretek oktatásának módszertani szempontjai. Müszaki Tudományos Füzetek, 19. (2014) 73-76.

https://doi.org/10.36243/fmtu-2014.011

[5] Okoň W.: Felsőoktatási didaktika. Felsőoktatási Pedagógiai Kutatóközpont, Budapest, 1973.

[6] Kietliňskja Z.: A müszaki felsőoktatás pedagógiája. Felsőoktatási Pedagógiai Kutatóközpont, Budapest, 1974.

[7] Szűcs P.: Video kézikönyv. OMIKK, Budapest, 1985.

[8] Varga L., Pék A.: Pedagógia a számítógépek korában. LSI Alkalmazástechnikai Tanácsadó Szolgálat, Budapest, 1988.

[9] Kovács M.: A számítógép hasznosítása a felsőoktatásban. Felsőoktatási Szemle, 36/7-8. (1987) 464-471. 